\title{
Public Memory Meets Archival Memory: The Interpretation of Williamsburg's Secretary's Office*
}

\section{Richard J. Cox}

The author expresses appreciation to the staff of the Colonial Williamsburg Foundation Archives and John D. Rockefeller Library, Colonial Williamsburg, especially Donna Cooke and Del Moore, for their assistance at their repositories. This essay was originally prepared for a presentation at the Second International Conference on the History of Records and Archives, held in Amsterdam, Netherlands, in September 2005.

\begin{abstract}
One of the restored buildings in the Colonial Williamsburg historic site is the Secretary's Office, built in 1747-48, the oldest public records structure in the Englishspeaking colonies. Probably few archivists and other records professionals know that the antecedents of their profession are well represented in such a popular tourist attraction. This essay considers three lessons for archivists in their quest for greater public understanding and support, drawing on how this old public records structure has been interpreted. First, the essay suggests that the story of the Secretary's Office is not well known by archivists and those interested in the history of efforts to preserve our documentary heritage. Second, the essay recounts the story of the failure by America's premier and pioneering historic site to interpret fully the legacy of the public
\end{abstract}

*First published: The American Archivist, vol. 68, no. 2. Published by permission of the Society of American Archivists, http://www.archivists.org/. 
Richard J. Cox: Public Memory Meets Archival Memory: The Interpretation of Williamsburg's Secretary's Office

records office. Finally, the essay indicates that the lack of interpretation represents a lost opportunity to promote public understanding of what records represent, why archives are important, and the work of archivists.

One of the most famous streets in America is the Duke of Gloucester Street in Williamsburg, Virginia. Stretching a mile, with the College of William and Mary at one end and the Capitol building, seat of government for the Virginia Colony, at the other, this street has witnessed more scenes of historical importance and hosted more tourists than any other street in the nation. President Franklin Delano Roosevelt, dedicating the restored street on 20 October 1934, declared it to be the "most historic avenue in all America." ${ }^{1}$ On either side of the length of the elegantly tree-lined thoroughfare are quaint shops and beautiful colonial homes, now pristinely managed as part of America's earliest and best-known historic site.

As you walk leisurely down this street toward the stately Capitol building, a compact one-story brick structure just off to the left of the government seat barely catches your eye. Described by Marcus Whiffen in his architectural history of the town as a "handsome little building, ${ }^{2}$ with its distinctive Flemish bond brickwork and rubbed brick doorway, the building is the Secretary's Office, for a long time referred to as the Public Records Office by Colonial Williamsburg

\footnotetext{
${ }^{1}$ Anders Greenspan, Creating Colonial Williamsburg (Washington, D.C.: Smithsonian Institution Press, 2002), 41.

${ }^{2}$ Marcus Whiffen, The Public Buildings of Williamsburg Colonial Capital of Virginia: An Architectural Library (Williamsburg, Va.: Colonial Williamsburg, 1958), 131.
} 
historians and interpreters. ${ }^{3}$ The structure was built in $1747-48$, just after the Capitol building burned to the ground, and it is the only original Colonial central government building extant. How many archivists and other records professionals know that the cradle of their profession reposes on a street traversed by millions of tourists through the years?

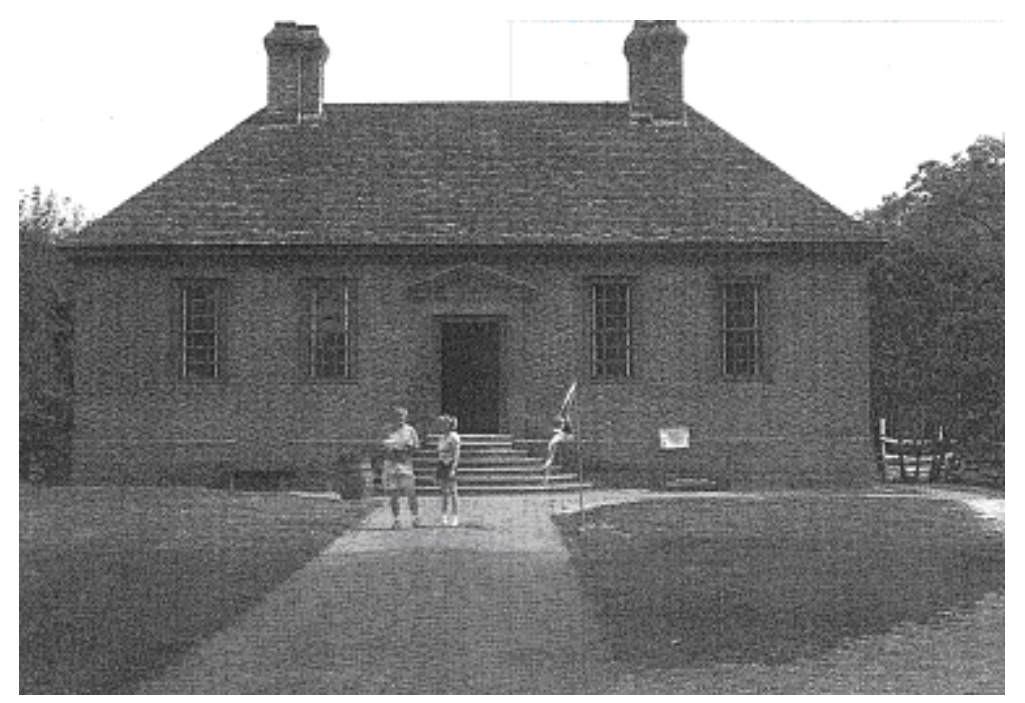

Figure 1. Front view of the Secretary's office (Photograph by the author, May 2005)

This essay considers three lessons for archivists in their quest for greater public understanding and support, drawing on how this old public records structure has been interpreted. First, it suggests that the story of the Secretary's Office is not well known by archivists and

\footnotetext{
${ }^{3}$ The building was called by both names in the past century, but it has been known as the Secretary's Office for at least the last two decades. As this essay suggests, the Public Records Office designation seems to have been a temporary creation of early interpreters of the building intending to explicitly indicate the structure's purpose.
} 
Richard J. Cox: Public Memory Meets Archival Memory: The Interpretation of Williamsburg's Secretary's Office

those interested in the history of efforts to preserve our documentary heritage. Second, it describes the failure by America's premier and pioneering historic site to interpret fully the legacy of this public records office. The result neither of neglect nor conspiracy, this failure simply reflects the challenges typical of explaining the archival mission to the public. Finally, the essay argues that the lack of interpretation represents a lost opportunity to promote public understanding of what records represent, why archives are important, and what archivists do.

Both archival and public memory have been weakened even though the 250-year-old Secretary's Office is one of the best-preserved original structures in Colonial Williamsburg. Constructed at a cost of a little over 367 pounds, the 56-by-24-foot building was completed by December 1748 . Designed to resist damage by fire, the main threat to records and books, it has no basement or attic, floors of paving stone, plastered walls and window jambs, and a minimum of exposed wood. The structure also includes four fireplaces, likely to keep out the infamous Tidewater humidity, a threat almost as insidious as fire. Consisting of three rooms -a large center room supposedly used by the secretary and his clerks for copying and referencing records, and two outer rooms, each probably used for records storage- the public records building is one of the smallest on the Duke of Gloucester Street, only some of the shops being smaller.

After Virginia's capital was moved to Richmond in 1781 , the Secretary's office was used as an office for the Court of Admiralty, then for the Chancery Court, and then as the home of the headmaster of a private grammar school (the school was briefly 
located in the old Capitol building). By 1855, the Secretary's Office was privately owned and altered with the addition of a frame structure on its west side. Colonial Williamsburg acquired the building in 1937 and restored its exterior in 1939-40, as it did with many of the other buildings in the area. The last owner of the structure, Mrs. David Rowland Jones, lived there until her death in 1964, at which point its restoration was completed.

From nearly the moment the notion developed for returning the sleepy early twentieth-century village of Williamsburg to its former glory as the eighteenth-century capital of Virginia, tourists flocked there to see what was going on. Rev. W. A. R. Goodwin, rector of Bruton Parish in Williamsburg generated the idea for the town's restoration in the early 1920 s and enlisted the financial support of John D. Rockefeller, Jr., in 1926 to provide the foundation for the creation of the outdoor history museum. By 1932, the first building, Raleigh Tavern, was open to the public, and by the end of that decade Williamsburg was already well established as a vacation and educational venue.

Many American families can chart their history by visits there, and mine is no exception. I went there as a young child in 1957, and the visit sparked my interest in history. I can vividly recall return visits in the 1960s. I honeymooned there in 1975, and I have been a regular there for conferences, golf (there are championship courses throughout the area), and research. My childhood recollections of the Secretary's Office are vague, but I remember it distinctly from the 1970s after I had commenced my archival career. 
Richard J. Cox: Public Memory Meets Archival Memory: The Interpretation of Williamsburg's Secretary's Office

Despite the significance of the Secretary's Office as a landmark in the history of American archives, records management, and public recordkeeping, the scholarship on these topics has generally ignored it. One of the earliest surveys of the history of the preservation of southern archives, made more than a decade after the creation of Colonial Williamsburg as an outdoor history museum, does not mention the building. ${ }^{4}$ Ernst Posner's important analysis of American government archives refers only in passing to the 1747 legislation that led to the construction of the building. ${ }^{5}$ Though it is featured in a few popular articles and sparse references in official guidebooks, researchers into the history of American archives and public recordkeeping have largely ignored the Secretary's Office.

There is some delicious irony in this. The Colonial Williamsburg endeavor has long been considered the critical benchmark for the modern historic preservation movement, partly because of its scrupulous attention to historical documentation; yet, Williamsburg provides little interpretation of the old public records office or scant inquiry into the nature, preservation, and use of archival records. Charles Hosmer, in his detailed history of the American historic preservation movement, describes how Williamsburg became the model for others to emulate, as well as a clearinghouse for information: "The work was a success by every standard: It was scholarly, it attracted a great many visitors, and it proved that large

4]. G. De Roulhac Hamilton, "Three Centuries of Southern Records, 1607-1907," Journal of Southern History 10 (February 1944): 3-36.

${ }^{5}$ Ernst Posner, American State Archives (Chicago: University of Chicago Press, 1964), 9. 
amounts of money could be put into preservation projects. ${ }^{\prime 6}$ Sitting, virtually silent, among all this effort was the public records office, the place where many of the records that would ultimately support the town's restoration had been originally preserved.

\section{Interpretation}

The building now known as the Secretary's Office was interpreted, if meagerly, almost from the founding of Colonial Williamsburg. The official 1935 guide to the restored town provided a brief eighty-nine word description, indicating the time of construction and making a modest reference to the building's purpose, its subsequent history, and its status then as a private residence. ${ }^{7}$ Thirty years later, the guidebook's successor expanded the coverage to about 150 words, adding just a little more detail about the building (about the structure, that is, not what was going on inside). ${ }^{8}$ Visitors who assiduously read the guidebook learned that it was a public records facility, that it was built to protect the records after the Capitol building burned, and that it had had a checkered history, mostly as a private residence, after the capital was moved to Richmond.

${ }^{6}$ Charles B. Hosmer, Jr., Preservation Comes of Age: From Williamsburg to the National Trust, 1926-1949 (Charlottesville: Published for the Preservation Press, National Trust for Historic Preservation in the United States, by the University Press of Virginia, 1981), I, 65, 67.

${ }^{7} A$ Guidebook for Williamsburg, Virginia (Williamsburg, Va.: Colonial Williamsburg, 1935), 33.

${ }^{8}$ Colonial Williamsburg Oficial Guidebook (Williamsburg, Va.: Colonial Williamsburg, 1964), 7-8. 
Richard J. Cox: Public Memory Meets Archival Memory: The Interpretation of Williamsburg's Secretary's Office

Besides such brief descriptions, the staff of Colonial Williamsburg put considerable energy into researching the records building (as they did with all of the structures and sites in the town). A 1938 report indicates that when townspeople and historians met to recommend a name for the structure, they settled on the Public Records Office (rather than the Clerk's Office or Chancery Office) because that name reflected the intent of the 1747 legislative act and because it was believed to be the first building in America designed for such a purpose. As this report indicates, the "building has a prestige which only such an explicit name could convey." ${ }^{\prime 9}$ About this time, an archaeological report of the building's site was completed as well, identifying the existence of two privies about forty feet away from the building (suggesting that archives and records centers have always had a preoccupation with restrooms). The same report also did an extensive analysis of the various initials and names carved into the soft brick around the doorway between the 1760s and the 1830s, providing the interesting idea that the building itself had become a kind of record. ${ }^{10}$

Research on the building continued. In 1945, Colonial Williamsburg completed a thorough architectural analysis to provide as much

\footnotetext{
9"The Public Records Office," Department of Research and Record, Colonial Williamsburg, Inc., 23 September 1938, 1937-38 Block 17, no. 12 Clerk's Office file, Colonial Williamsburg Foundation Archives (hereafter cited as CWF Archives).

${ }^{10}$ The initial archaeological excavations were completed in 1938. "Public Records Office (Block 17, Building 12) Archaeological Report," Colonial Williamsburg, Inc., Architectural Department, 28 February 1942, John D. Rockefeller Library, Colonial Williamsburg Foundation is the final report. The 1938 archaeological report is in the Special Collections at the Rockefeller Library, filed under Public Records Office, Archaeology Block 17, Building 12.
} 
information about the building's various uses as possible. The report's author, A. Lawrence Kocher, notes various changes to the structure, such as the covering of the stone floors with wood, but more interesting is his conclusion about how little documentation of the building exists. Kocher remarks that it was not known how the records would have been stored and that more research was needed about this aspect of the structure's history. ${ }^{11}$ Ironically, from this point on, substantial research seems mostly to have stopped.

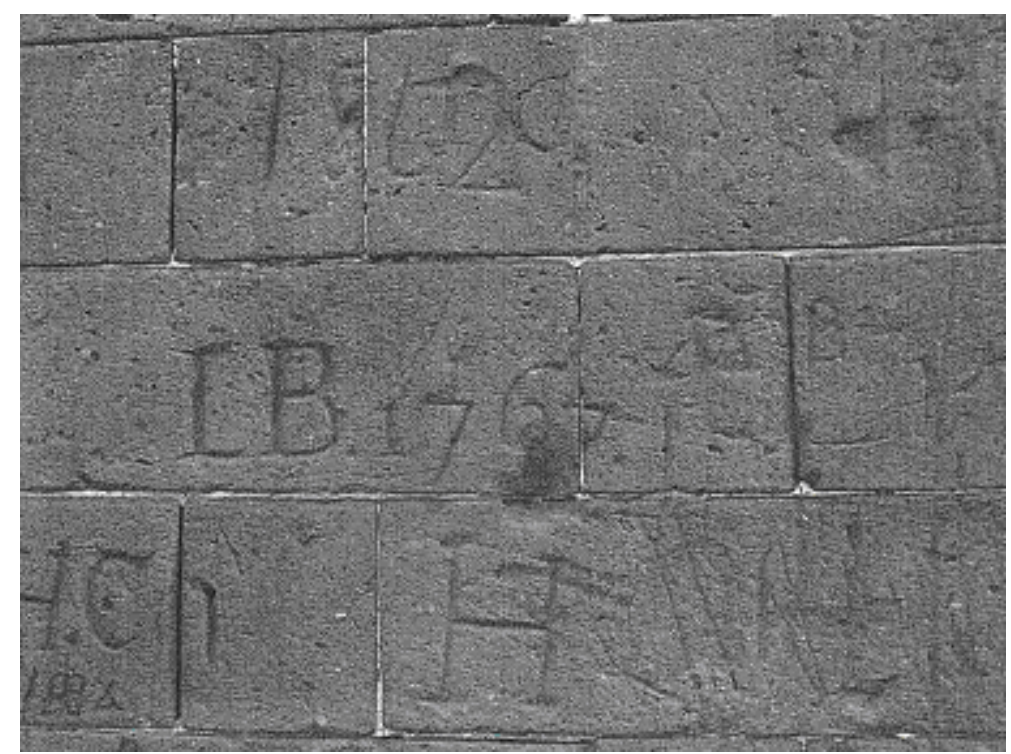

Figure 2. Detail of inscriptions on front door of the Secretary's office (Photograph by the author, May 2005)

\footnotetext{
${ }^{11} \mathrm{~A}$. Lawrence Kocher, "The Public Records Office (Secretary's Office of the Colony of Virginia)," Department of Architecture, Colonial Williamsburg, 22 September 1945, CWF Archives.
} 
Richard J. Cox: Public Memory Meets Archival Memory: The Interpretation of Williamsburg's Secretary's Office

By the 1970s, the Secretary's Office, no longer a private residence and open for use and interpretation by Colonial Williamsburg, housed changing public exhibitions. A fitting one, perhaps, mounted in 1976 marked the Bicentennial of the American evolution and the fiftieth anniversary of the Williamsburg restoration. ${ }^{12}$ Curiously, given its original construction and purpose, during this year the building suffered from a "humidity problem, ${ }^{13}$ which was quickly corrected. Soon it was being regularly used for changing exhibitions, often as part of the popular Williamsburg Antiques Forum, usually displaying portraits, furniture, and drawings. ${ }^{14}$ Some of the exhibitions were quite appropriate to the building's original use, as when a group of measured architectural drawings documenting thirteen of the Williamsburg buildings, including one of the Secretary's Office, went on display in $1979 .{ }^{15}$ The space also was used for a variety of other interpretive and administrative purposes and at least once for a

\footnotetext{
${ }^{12}$ The exhibition in the Secretary's Office was one of four around the restored capital, with the old public records building used to display Revolutionary War period maps; "Williamsburg Exhibits Mark Bicentennial Year, Fiftieth Anniversary of Restoration," 20 January 1976, CW press release, CWF Archives.

${ }^{13}$ R. E. Graham to P. L. Epley, 14 September 1976, 1948. Block 17, no. 12 PRO file, CWF Archives.

14"Wiliamsburg Antiques Forum Reflects Its Own Character," 6 December 1977, CW press release; "Antiques Forum Features Exhibition of Portraits," 9 January 1978, CW press release; "Westover Drawings to Be Shown at Antiques Forum," 17 January 1979, CW press release; "Two Special Antiques Forum Exhibitions Open to Public," 30 January 1980, CW press release, CWF Archives.

${ }^{15}$ These were drawings completed for the Historic American Buildings Survey; "Architectural Drawings Are Displayed in Williamsburg," 20 February 1979, CW press release, CWF Archives.
} 
Christmas tree decorating workshop during the restored capital's extremely popular holiday season. ${ }^{16}$

The increasing diversity of uses for the Secretary's Office was met with some internal discussion among various Colonial Williamsburg staff. In 1974, archivist Mary R. M. Goodwin, reacting to suggestions about how to utilize the building, indicated that if it was to be used for exhibitions of portraits and documents, it would be best "if it were properly interpreted." She saw only tenuous connection between portraits and records, but she would be happy if the building's convenience could be explained as the reason for such use. However, why not furnish it as the "Secretary's Office?" Goodwin attached a 1699 letter from Virginia governor Nicholson describing how rooms and boxes for records were used in the original Capitol building. ${ }^{17}$ The attachment suggested that while specific documentation about the interior uses of the Secretary's Office may not exist, documentation concerning how records were maintained during the Colonial era certainly did.

The lack of interpretation of the building as a records office bothered other Colonial Williamsburg insiders. In early 1976, discussion focused on the building needing "more definition from the outside" and interpretive labeling to identify the structure as the "first archival building in America and its superb condition for an original

\footnotetext{
16"Calendar of Events -December-February 1981-82," 2 November 1981, CW press release, CWF Archives.

${ }^{17}$ Mary R. M. Goodwin to Dr. Riley, 5 February 1974, 1948. Block 17, no. 12 PRO file, CWF Archives.
} 
Richard J. Cox: Public Memory Meets Archival Memory: The Interpretation of Williamsburg's Secretary's Office

building. ${ }^{18}$ Some of this discussion may have been prompted by the publication of the first major, if popular, essay on the public records office, written by Virginia's state archivist and published in the popular history and tourism serial Virginia Cavalcade. ${ }^{19}$ About this time, some more obvious rationales for the multifarious uses of the records office for exhibitions and other public programs surfaced. In an interview in early 1979, James R. Short, Colonial Williamsburg's vice president for preservation and research, explained that an exhibition there of measured drawings of Westover, William Byrd's magnificent home on the James River, made sense "because these drawings are public records." 20

In the early 1980s, a new possibility for the Secretary's Office opened up. In 1982, the Colonial Williamsburg Foundation received a $\$ 90,000$ grant from the Pew Freedom Trust Fund to assist in developing a new educational program focused on the "traditions of American citizenship." Five buildings in the historic district -the Capitol, the 1770 Courthouse, the Public Gaol, a law office, and the Secretary's Office- were to be included. As the press release announced, the grant would support research on "these structures as the setting for a

\footnotetext{
${ }^{18}$ Peter A. G. Brown to Mr. Short, February 12, 1976; E. M. Riley to Peter A. G. Brown, 8 April 1976, 1948... Block 17, no. 12 PRO file, CWF Archives.

${ }^{19}$ Louis $\mathrm{H}$. Manarin, "A building...for the preservation of the Public Records," Virginia Cavalcade 24 (Summer 1974): 22-31.

${ }^{20}$ Vicki Kelly, "Archival Drawings of CW Buildings to be Exhibited," Virginia Gazette, 17 January 1979, in Westover Exhibit folder, CWF Archives. The drawings were part of the Historic American Buildings Survey project.
} 
carefully integrated interpretation of the emergence of American citizenship during the colonial period." ${ }^{21}$

Six years later, the research for this project was still underway, with projections of the first phase being ready by 1989 . By then it had been renamed the "Legal Traditions Program," and it was intended to inform Colonial Williamsburg visitors "how ordinary people learned to conduct the public affairs of their community under the rule of law." The project's press release mentioned the "arduous task" of researching the 1770 Courthouse, since the burning of Richmond in 1865 destroyed "many local court records which ironically had been sent to the capitol for safe-keeping. Fifty years later, in 1911, a fire destroyed all but the exterior walls of the Courthouse itself." ${ }^{22}$ This parallels somewhat the history of the Secretary's Office, but note how the focus shifted to the Courthouse with no mention of the Secretary's Office, despite an understanding of how the loss of public records had made research for this educational effort more difficult.

Perhaps as a result of the study for this public programming, Colonial Williamsburg's popular magazine, distributed to its contributors and members, featured about this time an essay on the Secretary's Office. Written by Howard Gill, one of the restoration's historians, the essay described how Colonial Virginians had managed their records, the various calamities that befell these public records, and the circumstances of the 1747 Capitol fire and subsequent construction of

\footnotetext{
21"Pew Freedom Trust Fund to Assist Proposed CMT Citizenship Activity," 8 September 1982, CW press release, CWF Archives.

22"Colonial Williamsburg Completes Courthouse Research," 16 December 1986, CW press release, CWF Archives.
} 
Richard J. Cox: Public Memory Meets Archival Memory: The Interpretation of Williamsburg's Secretary's Office

the records building. The author states, "The designer's primary objective was to design a building especially for the preservation of records," declaring it, then, to be the "first archival structure in English America and possibly in the Western Hemisphere." Gill, obviously drawing on previous research done in the late 1930s and early 1940s, again indicates that little evidence remained about how the rooms were used, what the interior furnishings looked like, or even how the records were stored. ${ }^{23}$ Colonial Williamsburg's popular book, Williamsburg Before and After, also featured, nearly at the same time, a couple of pages on the records building, providing a bit more detail than its official guidebooks and, befitting its coffeetable market, including photographs of the structure as a private residence and after its restoration to its original appearance. ${ }^{24}$

The ultimate decision about the interpretation and use of the Secretary's Office came in 1988. Cary Carson, then director of research, considered a request from the Colonial Williamsburg Educational Administrators Group to use the building as a modern exhibition gallery, considering, as well, whether restoration for this purpose would meet the needs to describe the everyday work of the Secretary's Office. Carson, meeting with historians Carl Lounsbury and John Hemphill, reported, "It is their opinion that too little is known except about the use of the Public Records Office to make a strong case for its restoration as an exhibition building." It is unclear who worked in the building, and there is no evidence about how the

\footnotetext{
${ }^{23}$ Howard Gill, Jr., "Preserving the Public Records: A Building to Withstand the 'Flames and Injuries of Time,'" Colonial Williamsburg 9 (Spring 1987): 16-18 (quotation, 17).

${ }^{24}$ George Humphrey Yetter, Williamsburg Before and After: The Rebirth of Virginia's Colonial Capital (Williamsburg, Va.: Colonial Williamsburg Foundation, 1988), 78-79.
} 
records were stored. Carson continued: "The only thing that can be said for certain is that provincial court officials were eager to move their records out of the jailer's lodging into a newly built, fireproof record office." Approval was given for the building's "adaptive reuse" as an exhibition site. ${ }^{25}$ It seems that no new research about the building had been done, nor any additional investigation into eighteenth-century recordkeeping practices.

By the next decade, the Secretary's Office was being used for short public discussions, administrative offices, and a bookstore and gift shop. In the 1990s, it hosted an hour-long discussion on eighteenthcentury marriage. ${ }^{26}$ During this time, the citizenship project was finally completed and unveiled. The Secretary's Office became a "visitor service center" where individuals and groups could secure: "program information and tickets." Its main room was used to orient visitors to the story of the American Revolution from 1763 to 1781, and it housed an exhibition on pirates and a bookshop. Mostly, the building served as a "venue for historian talks -an opportunity for visitors to take an in-depth look at a particular historical topic." 27 When I last visited in May 2005, the center room was set up for lectures, the room on the right accommodated a bookstore and gift shop (as well as a place to buy tickets for entrance into the Colonial

\footnotetext{
${ }^{25}$ Cary Carson to Dennis O'Toole and Members of the Educational Administrators Group, 28 March 1988, Public Records Office file, Special Collections, John D. Rockefeller Library, Colonial Williamsburg Foundation.

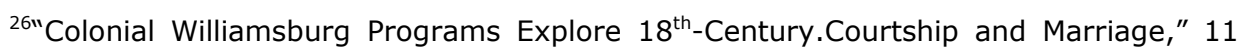
December 1996, CW press release, CWF Archives.

27"Capitol Tells Citizenship Story," Colonial Williamsburg News, 19 March 1998, CWF Archives.
} 
Richard J. Cox: Public Memory Meets Archival Memory: The Interpretation of Williamsburg's Secretary's Office

Williamsburg buildings), and the room on the left was closed with a sign indicating that it was being used for "Administrative Offices." ${ }^{28}$

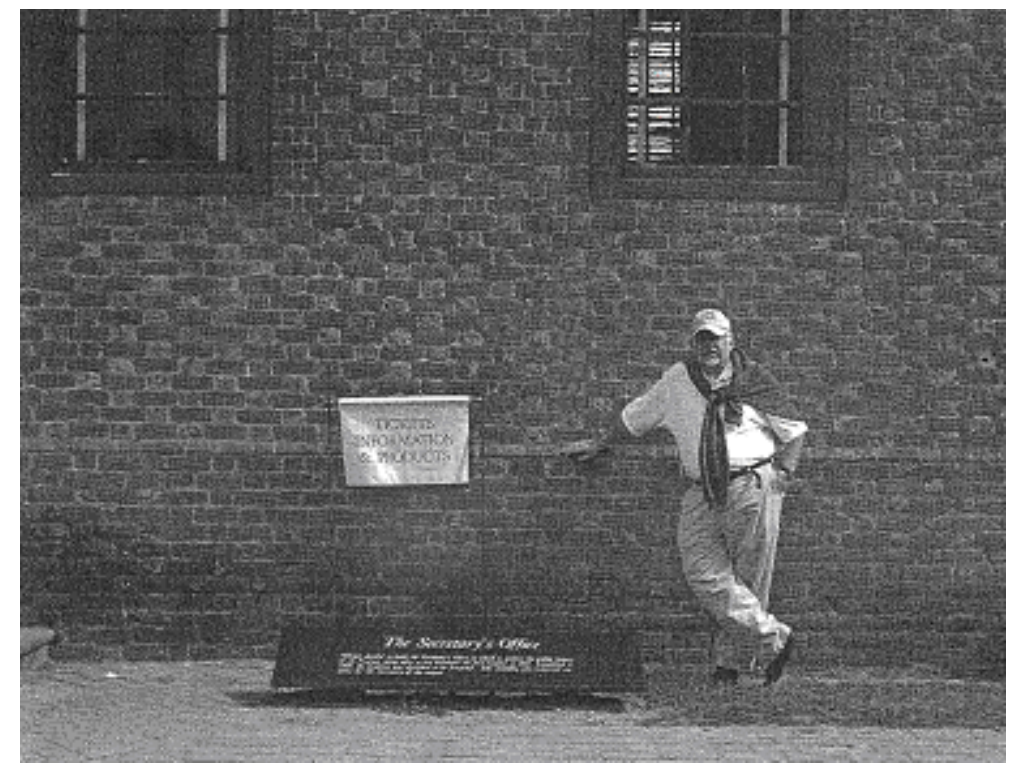

Figure 3. Signage at the Secretary's office (Photograph by the author, May 2005)

Another clue about the interpretation of the Secretary's Office can be found in the current official guidebook to the restoration, originally published in 1998. The guide briefly mentions the building's use for public records, the exhibition on pirates (dismantled), and the Secretary's Office's role in the orientation program entitled "Choosing Revolution." This presentation makes more information available about the care of public records. It includes a description of how the most important public records, both bound volumes and loose papers,

\footnotetext{
${ }^{28}$ Even the visitors' guide to monthly events marks the location of the Secretary's Office as a location for "Tickets, Treasures and Books," Colonial Williamsburg June 2005 Guide to Dining and Shopping.
} 
were stored in an office next to the General Courtroom in the Capitol building before the Secretary's Office was built.

The details of recordkeeping given in the modern guidebook seem to play on every stereotype imaginable: "There, the chief clerk and his deputy oversaw a vast domain of records in the form of bound volumes and of endless files of loose papers tied up in red tape that had been used by bureaucrats to secure legal and official documents since the seventeenth century. Here, generations of clerk-apprentices scribbled away, learning their trade." A description of the 1747 fire, a discussion about passing the legislative act to endorse the construction of a public records facility, comments on the nature of the construction of the building, and a look at how the secretary functioned all follow. ${ }^{29}$ Is it possible that Colonial Williamsburg historians, interpreters, and administrators simply wished to ignore the interpretation of the old public records office because records were boring to them or too boring for the visiting public? The references connecting records, red tape, and bureaucratic inertia seem too obvious, cute, or smug for the well-known historic site. At the least, the long-known fact that Thomas Jefferson, while a law student at the College of William and Mary, became interested in the condition of Virginia's early records and copied them as a means to preserve them, confiding that he "passed much time [from 1762 to 1775] in going through the public records in Virginia, then in the Secretary's office," opens up the possibilities of interpreting the more

${ }^{29}$ Official Guide to Colonial W Iliamsburg, new ed. (Williamsburg, Va.: Colonial Williamsburg Foundation, 1998), 29-30, 66-67 (quotation, p. 66). The guidebook is available in all the shops in the restored district and in local bookstores. 
Richard J. Cox: Public Memory Meets Archival Memory: The Interpretation of Williamsburg's Secretary's Office

important goal of preserving historical records so vital to Williamsburg's restoration. ${ }^{30}$

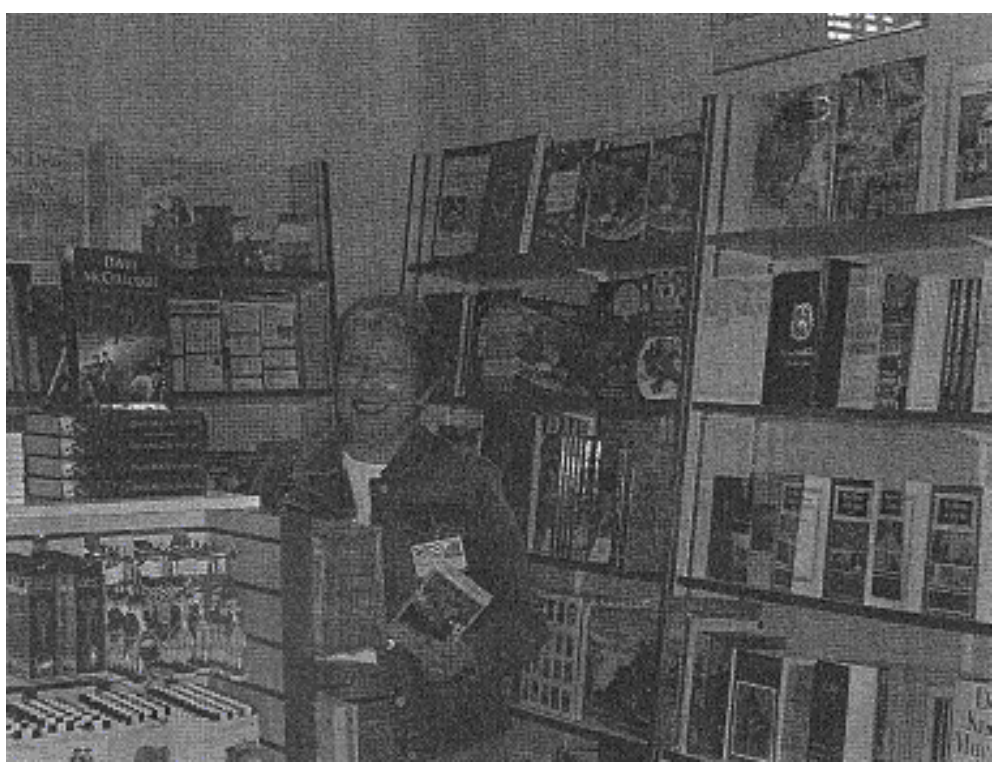

Figure 4. Gift shop and bookstore within the Secretary's office (Photograph by the author, May 2005)

\section{Opportunities Lost}

The archives and records management professions have not paid much attention to this rather unique structure and the story it tells

\footnotetext{
${ }^{30}$ Jefferson's reflections were cited as long ago as 1941 in Helen Duprey Bullock, "The Papers of Thomas Jefferson," American Archivist 4 (October 1941): 243-44 and later by Silvio A. Bedini, Thomas Jefferson and His Copying Machines (Charlottesville: University Press of Virginia, 1984), 2. Jefferson reflected on this copying, with specific reference to the Secretary's Office, in his 9 May 1798 letter to St. George Tucker, now published in Barbara G. Oberg, ed., The Papers of Thomas Jefferson (Princeton: Princeton University Press, 2003), 342.
} 
about society's lack of interest in public records in Williamsburg. There have been a few exceptions. In 1938, Morgan P. Robinson, head of the archives division of the Virginia State Library, wrote to Colonial Williamsburg's archivist, Helen Bullock, asking for assistance in making the case to change the name of the archives division to "public records office" by drawing documentation related to the Colonial records building. Robinson believed that the term "public records" was more understandable to most people. ${ }^{31}$ The name change never occurred.

Nearly forty years later, Louis Manarin, holding the same position as Robinson, wrote about the Secretary's Office: "It would be both educational and informative if the building would be opened with exhibits depicting recordkeeping methods of the eighteenth century: Such a presentation would pay tribute to the farsightedness of those early Virginians who first conceived 'a building for the preservation of the public records' and thus an example for the future. ${ }^{\prime 32}$ This may be the best observation, one that raises the most basic questions yet made regarding the Secretary's Office.

Others, from time to time, expressed an interest in the records structure. Morris Radoff, Maryland's State archivist, inquired about the building in 1950 and was told that little detailed documentation existed about the original erection of the building in 1747-48, but the "fact that the building was standing in a fair state of preservation

\footnotetext{
${ }^{31}$ Morgan P. Robinson to Helen Bullock, 16 November 1938; Helen Bullock to Mr. Geddy, 19 November 1938, 1937-38 Block 17, no. 12 Clerk's Office file, CWF Archives. ${ }^{32}$ Manarin, "A building," 31.
} 
Richard J. Cox: Public Memory Meets Archival Memory: The Interpretation of Williamsburg's Secretary's Office

when its restoration was undertaken, more than makes up for this. ${ }^{\prime 33}$ In 1954, John Melville Jennings, director of the Virginia Historical Society, also inquired about the uses of the building, and he received a five-page letter describing the care of colonial-era public records, mostly summarizing earlier research. ${ }^{34}$ Yet, in general, with the exception of Manarin's popular essay, the archives and records management community has expressed little interest in the Secretary's Office, and no stream of requests pours in to anyone at Colonial Williamsburg seeking to have the old public records office better interpreted as a landmark in the development of North American archives and records management.

Other questions must be asked, however, regarding the use and interpretation of the public records office. Given Colonial Williamsburg's reputation for meticulous research about its buildings, artifacts, and other historical collections, we might simply accept the argument that little direct evidence can be mustered to more fully interpret the building as an early records facility. In a description

\footnotetext{
${ }^{33}$ Mrs. Rutherford Goodwin to Morris L. Radoff, 30 August 1950, Research Queries File, John D. Rockefeller Library, Colonial Williamsburg Foundation. It is likely that Radoff was working on what became his Buildings of the State of Maryland at Annapolis (Annapolis: Hall of Records Commission, 1954), trying to ascertain whether Maryland had, in fact, the oldest public records structure in North America. A repository had been authorized in 1729 and some documentary evidence indicates that it was used. It may be that the old structure on the State Circle near the capitol building known as the "old treasury building" may have been originally built for storing public records. The problem may be that the identification of the structure is far less certain than it is for the old public records office in Williamsburg, making the latter's claim for the oldest extant records repository the more certain.

${ }^{34}$ Mrs. Rutherford Goodbin to John Melville Jennings, 1 July 1954, Research Queries File, John D. Rockefeller Library, Colonial Williamsburg Foundation.
} 
about the 1980 s research on the eighteenth-century courts and legal practices program, which originally included the Secretary's Office, John Krugler attests to the type of research Colonial Williamsburg did, when its "research department undertook extensive field investigations on courthouses and other public buildings in the southern colonies and England." Mostly aimed at gathering data for use in the restoration of the 1770 Courthouse, ${ }^{35}$ none of this work seems to have influenced how the public records office was interpreted or to have reopened discussion about the interpretation of the structure that seems to have been firmly in place for forty years.

Another way of questioning this, however, certainly suggests some deepseated problems with public understanding of the administration of archives and records. At all historic sites, accurate interpretation and sound, ongoing professional educational programs depend on the existence and use of historical documentation. This has been a hallmark of Colonial Williamsburg's work. As I worked my way through its own archives, I easily saw the painstaking efforts to gather and evaluate documents regarding the Secretary's Office, supplemented by archaeological and architectural analysis. One of the major contributions of the Williamsburg historic site has been its effort to interpret more fully the Colonial experience, utilizing the best of social history methodologies. In the early 1980s, as the interpretive possibilities of the Secretary's Office dwindled, the York County Project geared up under the able direction of Cary Carson. Its purpose was to gather information from extant public records about

\footnotetext{
${ }^{35}$ John D. Krugler, "Behind the Public Presentations: Research and Scholarship at Living History Museums of Early America," William and Mary Quarterly, 3rd ser., 48 (July 1991): 365.
} 
Richard J. Cox: Public Memory Meets Archival Memory: The Interpretation of Williamsburg's Secretary's Office

every eighteenth-century inhabitant of the Williamsburg region, amassing a major archives of its own data.

In addition to this project, the Colonial Williamsburg Foundation has a major research library for its own purposes, the John D. Rockefeller, Jr. Library, holding "72,000 volumes, 12,500 rare books, 150 manuscript collections comprising 50,000 manuscript pages dating largely from the eighteenth century. There are 50,000 architectural drawings, 6,000 reels or microfilm, 10,000 micro-fiches, and 500,000 images, most of them photographs." ${ }^{\prime 36}$ The entire Colonial Williamsburg enterprise has been built around the gathering of archival sources. In 1955, it, along with the Virginia Historical Society, the University of Virginia Library, and the Virginia State Library, began an initiative to build a massive documentary archives by identifying and copying Virginia-related records in the libraries and archives of Great Britain, Ireland, and France, resulting in 963 microfilm reels by its conclusion in $1985 .{ }^{37}$ So, why could the old public records office not be used as a place to educate the public about the nature of archival and other research needed to support the day-to-day interpretations of the historic site?

Additional clues surfaced in a controversy, emerging in the mid1990s, about the general interpretive and educational programs going on at Colonial Williamsburg. Two anthropologists, Eric Gable

${ }^{36}$ Philip Kopper, Colonial Williamsburg, 2nd ed. (NewYork: Harry N. Abrams, Inc., in association with the Colonial Williamsburg Foundation, 2001), pp. 203-4, 246.

${ }^{37}$ Edward M. Riley, "The Virginia Colonial Records Project," National Genealogical Society Quarterly 51, no. 2 (1963): 81-89, and John T. Kneebone, "The Virginia Colonial Records Project," Perspectives: American Historical Association Newsletter 30 (September 1992): 15-16, 18, 20. 
and Richard Handler, conducting research on the interpretive activities of history museums, used Colonial Williamsburg as a case study. As they reported in early findings of their work, "Touring the museum repeatedly, we listened as interpreters routinely told the public that history changes because new documents revealing new facts are found." They described in detail how interpreters were provided packets of artifacts and documents for their use, and, at a later date, each building at Colonial Williamsburg made available a notebook with information on all displayed artifacts for the use of its guides and craftspeople. What made the pair's work so controversial was their conclusion that the methods of training, evaluating, and administering the interpreters revealed a complex hierarchy of control and accountability that went far beyond the general business of educating visitors to the site. ${ }^{38}$ Most interesting here, given the focus on the old public records office, is not the substance of their study, and certainly not the more controversial aspects of their work, but rather that a considerable part of their investigation had to do with how interpretive activities at history museums use documentary evidence.

Cary Carson, the head of research at Colonial Williamsburg, paved the way for the anthropologists to do the study, hoping to learn some things that would enhance the educational programs of the historic site. Carson reveals an interesting perspective on the importance of

\footnotetext{
${ }^{38}$ Eric Gable and Richard Handler, "The Authority of Documents at Some American History Museums," Journal of American History 81 (June 1994): 119-36 (quotation, 121). They ultimately published a fuller study, The New History in an Old Museum: Creating the Past at Colonial Williamsburg (Durham, N.C.: Duke University Press, 1997).
} 
Richard J. Cox: Public Memory Meets Archival Memory: The Interpretation of Williamsburg's Secretary's Office

documentary evidence, questioning much of the anthropologists' work and noting that it is "consistent with a mythology widely held by university academics, untold numbers of the general public, and even some conspiracy theorists employed by museums thernselves." 39 Indeed, Carson, an innovative museum administrator and accomplished scholar, effectively debunks many of the points made by Gable and Handler.

Carson's analysis of their commentary on the authority of documents should most interest archivists and other records professionals. Carson indicates that the two "anthropologists have shed light on current practices at Colonial Williamsburg that need correction and improvement." Carson is careful to note, however, that the "historians and trainers can do a better job of explaining to interpreters that there are pedagogical reasons for the selection of the primary sources used in training sessions." And here is the most critical aspect of Carson's statement: "Documents and artifacts do not speak for themselves. They reveal their meaning through the historians and teachers who select some in preference to others, arrange them in one order rather than another, and interpret them to mean this, not that. Every interpreter needs to understand this creative process, whether or not he or she makes that idea explicit to others. ${ }^{\prime 40}$ With this latter statement, we nearly have in hand a script for what the Secretary's Office could be used to interpret, both for the training of its own guides and the education of the public (unless we

\footnotetext{
${ }^{39}$ Cary Carson, "Lost in the Fun House: A Commentary on Anthropologists' First Contact with History Museums," Journal of American History 81 (June 1994) : 139.

${ }^{40}$ Carson, "Lost in the Fun House," 141. 
accept that such matters may be too mundane or uninteresting to exhibit).

Crafting a successful public exhibition is no easy task. Museum specialist Barbara Franco, also contributing to the issue of the Journal of American History that features Carson's exchange with the anthropologists, argues, "Exhibitions must consider the needs and desires of the public as the primary audience, merge education and entertainment, and integrate serious content with effective communication." ${ }^{41}$ Thinking along these lines, it is easy to imagine why the old public records office remains largely uninterpreted, except for identifying its original function describing lightheartedly in official guidebooks the red tape and bureaucratic aspects of government recordkeeping.

However, Franco is not done with her assessment about the purpose and nature of museum exhibitions:

My own experience at the Minnesota Historical Society suggests that reexamination of long-standing assumptions and arguments about historical methodology is also needed to reestablish history as a discipline central to public understanding of how past events relate to the present. The distinction between a scientific and objective process of research and analysis and a suspiciously subjective process of communication is no longer tenable. The public is more than willing to engage difficult subjects and complex meanings in exhibits that do not avoid emotion.... ${ }^{42}$

\footnotetext{
${ }^{41}$ Barbara Franco, "The Communication Conundrum: What Is the Message? Who Is Listening?" Journal of American History 81 (June 1994): 152.

${ }^{42}$ Franco, "The Communication Conundrum," 162-3.
} 
Like Carson's rebuttal, this statement suggests trying to educate the public directly about how historical documentation has played a role in more recent interpretative programs at places such as Colonial Williamsburg. Of course, the public already senses that something is up, as returning visitors discover more interpretation of AfricanAmericans, women, lower classes, and everyday life in addition to the political, economic, and upper-class orientation that Colonial Williamsburg once doted on.

Another barrier may have impeded the interpretation of the Secretary's Office over the years. Stuart Hobbs, also examining how history museums and historic sites have interpreted the past, discusses the ancient split between architectural historians and other historians in such venues, noting how the architectural historians have often focused on buildings rather than on archival research. Hobbs writes: "Members of the newly professionalizing museum field felt alienated from academic historians who focused on printed rather than material sources and scholarly rather than popular audiences. History museum professionals found intellectual and institutional allies in architectural and art historians, and curators of decorative arts at art museums. ${ }^{\prime \prime 3}$

Looking back, the history of the interpretation of the Secretary's Office at Colonial Williamsburg can be read as a focus more on its architecture than on its function. The problems with the interpretation, exhibition, and public programs related to the building

\footnotetext{
${ }^{43}$ Stuart D. Hobbs, "Exhibiting Antimodernism: History, Memory, and the Aestheticized Past in Mid-Twentieth-Century America," Public Historian 23 (Summer 2001): 59.
} 
beg questions about how much more, or how much less, is known about other structures in the Colonial Williamsburg complex that are more fully interpreted. For example, anthropologists Gable and Handler focus on the interpretation of one building (the Wythe House) and the use of document packets by the interpreters, noting that "all such artifacts and those in the main house itself, were conjectured in the sense that there are no surviving records of the furnishings of the property. ${ }^{\prime 44}$ I suspect that there is enough evidence from the many Colonial-era public records inspections, with many Colonial governments doing such an investigation nearly every generation from the late seventeenth century through the next century, that an engaging and accurate interpretation of the old public records could be done. ${ }^{45}$

Such criticisms must be put, however, into a fuller context, one that archivists and records professionals ought to understand as they have experimented with public programs, educational efforts, and advocacy to deepen understanding about the importance of records. Part of the charm and interest of Colonial Williamsburg for many are its architecture, pleasant streets, re-creations of street festivals, dining experiences, and shopping for everything from the garish sweatshirts long associated with popular tourist sites to very expensive reproductions of furniture and decorative arts. While visitors come to learn, they also come to be entertained. For many, the Secretary's Office is a pleasant bit of architecture, and more than

\footnotetext{
${ }^{44}$ Gable and Handler, "The Authority of Documents," 129.

${ }^{45}$ See, for example, H. G. Jones, For History's Sake: The Preservation and Publication of North Carolina Histoy 1663-1903 (Chapel Hill: University of North Carolina Press, 1966).
} 
Richard J. Cox: Public Memory Meets Archival Memory: The Interpretation of Williamsburg's Secretary's Office

one visitor has surely contemplated how to transform it into a comfortable suburban tract house. Would visitors go into the building to learn about Colonial recordkeeping, the challenges of preserving such records, and the even greater challenges of utilizing the historical documentation to understand and present the history of Colonial Williamsburg? We don't know, because it has not been tried. However, we can speculate about how this might work.

\section{Conclusion}

The year 2007 will mark the $400^{\text {th }}$ anniversary of the founding of Virginia, as well the fiftieth anniversary of my first visit to the historic village. I hope that when I visit there again, as I am sure I will, I can tour a functioning and dynamic Secretary's Office. I envision entering into the main, central room and seeing an exhibition about the history of recordkeeping with explanation about how the Colonial Williamsburg restoration has made use of the archival documentation. The history of recordkeeping could extend from the Colonial era, when the building was built, up to the present, considering some of the calamities that have befallen the older records through fire, natural disaster, neglect, and wars. The exhibition even could touch on the challenges posed by modern digital technologies, educating the present generation about the importance of records and why no one should take for granted what happens with their electronic mail messages, Web sites, and digital photographs.

I hope that the room off to the left of the center room, the one now used for administrative offices, can be turned into a living exhibition 
about the production of records. Just as the visitor to Colonial Williamsburg can enter the printing office and see how books and newspapers were printed, bound, and marketed, why should he or she not see an apprentice scribe copying a record, indexing a record, storing a document in a box, or retrieving a document for a public official? Here the visitor could ask the interpreter about the making and keeping of documents, the quaint spellings, and the learning of the Chancery hand used in the making of official records. He or she might inquire about the nature of older records systems that, today, support both the interpretation of the eighteenth-century town and the modern genealogist's quest for ancestors (something with which most visitors will probably identify).

Perhaps, walking back into the far room, the visitor could find a bookstore and gift shop. This shop would feature both scholarly and popular publications (along with multimedia publications) on the nature of archives and manuscripts, genealogical and historical research, historic preservation, and items related to calligraphy or with some other connection to the creation or maintenance of records. The Secretary's Office could be the one place in Colonial Williamsburg focused on preserving the documentary and material heritages and the relationship between the two. Given the amount of popular literature now available on such topics, the only difficult task would be fitting all the materials into the relatively small room.

Obviously, I am not an exhibit designer and there may be flaws with my ideas, but I do not think that what I describe here is too ridiculous or far from the range of activities that this history museum now supports. That the Secretary's Office is now a largely silent 
Richard J. Cox: Public Memory Meets Archival Memory: The Interpretation of Williamsburg's Secretary's Office

witness to generations of archival and records work should make archivists and records managers unhappy. And it should make administrators and scholars of Colonial Williamsburg discontent, given the possibilities for engaging the public about some important matters related to the American experience and the interpretation of the site. Each year, hundreds of thousands of visitors walk about the old public records office, mostly missing any sense of the importance of such an operation to the history of their nation or the Revolutionary legacy. No generation was likely more concerned with preserving the legacy of its own deeds than that of Thomas Jefferson and his compatriots, many of whose public careers had their start just down the street from the Secretary's Office. This part of the story of Colonial Williamsburg and the formation of the American experience is not being told well enough. The Secretary's Office deserves more than a modest sign and a brief entry in a guidebook. 